\title{
Multiple Fatal Intoxications Caused by Improper Consumption of an Alcoholic Para-Pharmaceutical Product
}

\author{
CAMELIA LIANA BUHAS ${ }^{1,2}$, BOGDAN ADRIAN BUHAS 3 , LUCIA GEORGETA DAINA4, BIANCA HANGANU5*, \\ IRINA SMARANDA MANOILESCU5,7*, CLAUDIA TEODORA J UDEA PUSTA ${ }^{1,2}$, ANDREEA ALEXANDRA HLESCU ${ }^{5,7 *}$, \\ CORNELIA MIRCEA ${ }^{6}$, MIHAELA CRISTINA SOMLEA ${ }^{8}$, PAULA MARIAN ${ }^{9,10}$, BEATRICE GABRIELA IOAN ${ }^{5,7}$ \\ 'Bihor County Forensic Service, 50 Calea Clujului, 410053, Oradea, Romania \\ ${ }^{2} O$ radea University, Faculty of Medicine and Pharmacy, Department of Morphological Disciplines, 1 Universitatii Str., 410087,0radea, \\ Romania \\ ${ }^{3}$ County Clinical Emergency Hospital, 65 - 70 Doja Gheorghe Str., 410169, Oradea, Romania \\ ${ }^{4}$ Oradea University, Faculty of Medicine and Pharmacy, Department of Psycho-Neuroscience and Rehabilitation, 1 Universitatii \\ Str., 410087, Oradea, Romania \\ ${ }^{5}$ Grigore T. Popa University of Medicine and Pharmacy, Discipline of Legal Medicine, 16 Universitatii Str., 700115, Iasi, Romania \\ ${ }^{6}$ Grigore T. Popa University of Medicine and Pharmacy, Department of Pharmaceutical Biochemistry and Clinical Laboratory, \\ lasi, Romania \\ IInstitute of Legal Medicine, 4 Buna Vestire Str., 700455, Iasi, Romania \\ ${ }^{8}$ County Clinic Emergency Hospital, Dermatovenerology Clinics, 3-5 Clinicilor Str., 400000, Cluj-Napoca, Cluj, Romania \\ ${ }^{9}$ Oradea University, Faculty of Medicine and Pharmacy, Department of Medical Disciplines,1 Universitatii Str., 410087,0radea, \\ Romania \\ ${ }^{10}$ Municipal Clinical Hospital Dr. G. Curteanu, 12 Corneliu Coposu Str., 410469, Oradea, Romania
}

\begin{abstract}
Ingestion of cheap para-pharmaceuticals (such as disinfectants, deodorizing solutions, etc.) which are designed only for external use is an unfortunate habit encountered in the recent decades in the economically disadvantaged areas of Romania inhabited by poor, uninformed, and sanitary uneducated population. These para-pharmaceutical products are based on different concentrations of ethanol. Occasionally, the manufacturer modifies the product formula, or worse omits on the label that the ethanol was replaced with methanol, resulting in mass poisoning with a large number of casualties. The authors present a case of mass poisoning by methanol that occurred during one month and resulted in 40 cases of methanol intoxication. Only 5 out of the 40 victims survived the intoxication. All the dead victims underwent medico-legal autopsy which revealed only general features, liable to poisoning. The toxicological examination result was positive formethanol in all the cases. All the intoxicated victims were homeless; they were heavy ethanol consumers, especially of the product rubbing alcohol. The male: female ratio was 31:4 and the age range was between 25 and 70 years old, with an average of 50 years. All the victims were hospitalized in deep coma, showing obvious pathological changes specific to chronic ethanol consumption. Conclusions: some alcoholic parapharmaceutical products manufactured for external use are ingested by chronic ethanol drinkers. When these products contain methanol, they can cause severe intoxication followed by an impressively large number of deaths.
\end{abstract}

Keywords: alcoholic para-pharmaceutical, methanol, ethanol, intoxication, death

Ethanol (ethyl alcohol) consumption in Romania is high. According to the WHO statistics in 2016, Romania ranks the top 5 countries in Europe for ethanol consumption, with a total average consumption of 12.6 liters of pure alcohol per capita (15+) [1-3]. Romanians prefer hard liquor with an alcohol concentration exceeding $40 \%$ volume, and either wine or beer [4]. The WHO statistics show that in the distribution on types of beverages, $56 \%$ of the total amount is covered by beer, followed by wine (28\%) and spirits (16\%) [1]. Severe intoxications with ethanol are still rare, and the alcohol tolerance is usually good; therefore, we might encounter blood alcohol concentrations of 3.8 to $4 \mathrm{~g} \%$ in living persons [2].

Methanol (methyl alcohol) is a low molecular weight alcohol in the form of a volatile and colorless liquid with characteristics and smell like ethanol, which burns slightly with high caloric power. It is used in solvent and alcoholic disinfectants composition, antifreeze solutions, photocopying, and typography or in denaturation of ethanol.
It can be consumed for suicidal purposes or by accident because it can be easily confused with ethanol, or due to the consumption of counterfeit products that theoretically contain as basic substance ethanol but which is sometimes replaced in large parts with methanol $[5,6]$. Alcohol use, psychiatric disorders and suicide are intimately connected. Acute alcohol use and alcohol dependence are important risk factors for suicidal behavior and increase suicide risk rate $[7,8]$.

In Romania, methanol intoxication is rarely encountered in forensic medicine practice [4]; most of the cases occur among the chronically degraded persons, such as the homeless [9]. They are usually consumers of sanitary alcohol, a product marketed under different trade names, based on denatured ethanol mixed with different substances (e.g. methylene blue, ethyl salicylate) giving it a specific color and an unpleasant taste [2, 9]. The sanitary alcohol intended only for external use contains ethanol, therefore it is quite common to be drank since it is

\footnotetext{
*email: bianca-hanganu@umfiasi.ro; manoilescuirina@yahoo.com;
} andreea.velnic@yahoo.com 
inexpensive and has a high concentration of alcohol (70 volume\%), which allows it to be diluted with other substances giving it a better taste $[9,10]$. Sometimes this product contains a sufficiently high concentration of methanol to produce fatal poisoning by ingestion.

The purpose of this paper is to present a case of collective intoxication with methanol, as well as the manner in which this case has been dealt with from the forensic perspective. The authors underline the essential role of the toxicological examination in determining the cause of death in such cases and also the importance of the correct labeling of the alcoholic para-pharmaceutical products for preventing intoxications with powerful toxics, such as methanol.

\section{Experimental part}

\section{Material and method}

Case presentation

In the spring of 2013 in the Romanian county of Bihor, during a short period of time- one month, 40 cases of methanol intoxication were registered; all intoxicated persons belonged to the chronic alcoholic category, while some of them were homeless persons. Only 5 out of the 40 persons survived the intoxication. The deceased victims underwent medico-legal autopsy at the Medico-Legal Service of Bihor County. The macroscopic examination revealed unspecific features which are frequently encountered in intoxications [11, 12].

\section{Biological samples}

Blood, urine and gastric content samples were collected from the 35 deceased victims during the medico-legal autopsy. Sample collection was made according to standard procedure, in clean containers, sealed and labeled with identification data for each case [13-16]. The samples were kept in the fridge and transported in safe conditions to the Forensic Toxicology Laboratory of the Institute of Legal Medicine of Timisoara in order to perform the toxicological analysis.

\section{Sample analysis}

Volatile toxic compounds present in the biological samples (blood, urine, gastric content) were isolated by simple distillation, this method allowing to efficiently separating the methanol and ethanol due to the boiling point below $100^{\circ} \mathrm{C}$. The homogenized analyzing sample is acidified with a solution of tartaric acid $10 \%$ or oxalic acid $10 \%$, adding in the solution subjected to distillation the necessary amount of acid in order to obtain a weak acidic medium ( $\mathrm{pH}=5)$ [17]. The obtained distillate is used for identification and quantitative determination of the alcohols.

The ethanol can be determined by iodometric method and by gas-chromatography. lodometric method (Cordebard) consists in cold oxidation of ethanol to acetic acid, with potassium dichromate in nitric acid medium. The excess of potassium dichromate is titrated iodometrically, in the presence of starch as indicator [1820].

Methanol is determined by spectrophotometry and gaschromatography. Spectrophotometry with chromotropic acid is based on methanol oxidation to formaldehyde, which is then treated with chromotropic acid in acidic medium, obtaining a purple compound, with maximum absorbance at $580 \mathrm{~nm}$. The values of the obtained absorbents for samples are referred to calibration curve, previously prepared $[17,18]$.

The toxicological analysis of the samples collected from the cases was performed by gas-chromatography, using a
Pakard Model 417 Gas Chromatograph equipped with a flame ionization detector (FID). Column stuffing: Porapak Q, 80-100 mesh, $1.8 \mathrm{~m}$ length, and internal diameter of 2 $\mathrm{mm}$. Working conditions: column temperature $180^{\circ} \mathrm{C}$, injector temperature $220^{\circ} \mathrm{C}$, detector temperature $250^{\circ} \mathrm{C}$. Nitrogen carrier gas, with a flow rate of $40 \mathrm{~mL} / \mathrm{min}$; Hydrogen flow rate - $30 \mathrm{~mL} / \mathrm{min}$; Air flow rate $-300 \mathrm{~mL}$ / min. The internal standard was isopropyl alcohol.

\section{Results and discussions}

The range of the cases was initially limited ( 9 cases out of a single area); later, sporadically, cases appeared throughout the county. Finally, there were a total of 35 deceased patients examined by medico-legal autopsy. The age of the victims ranged from 25 to 70 years old. Male: female ratio was significantly in favor of males (only 4 out of the 31 cases were female). Two thirds of the victims lived in rural areas.

The autopsy performed in these cases revealed red cadaveric lividities, generalized visceral stasis, meningeal bleeding, acute pulmonary edema or hemorrhagic aspect of the lungs and fatty liver dystrophy. Microscopic examination revealed cerebral hemorrhagic areas and kidneybleeding.

\section{Toxicological analysis}

Chromatographic columns represent extremely important components of the analytical system. Inside the chromatographic columns takes place the separation of the components of a certain sample and these columns must be so chosen as to correspond to the requirements imposed by the specificity parameter. Specificity is the characteristic of an analytical system to univocally identify a certain analyte in the presence of other analytes that may be present in the analyzing sample.

Chromatographic columns separate the components of a sample and must be chosen to meet the requirements of the specific parameter.

Biological samples may contain, in addition to ethanol, weighed amounts of the following components:

-acetaldehyde (a metabolite of ethanol),

-methanol (as an accompaniment to ethanol in beverages and/or intoxications),

-acetone,

-isopropyl alcohol, metabolically linked to acetone by reducing it, or in intoxications with isopropanol,

-n-propyl alcohol, accompanied by postmortem ethanol, -other volatile substances formed in some particular circumstances (n-butyl alcohol, ethyl acetate).

In routine analyzes, the analytical system must be able to separate and identify the above compounds on both chromatographic columns in order to interfere with ethanol and/or with the internal standard.

In the first part of our study the analysis was performed using a Pakard Model 417 gas chromatograph that worked with a single chromatographic column. Determinations were made on the distillates in the samples. The identification and determination of methanol was made concurrently with ethanol (on the same distillate). Concentration calculations were performed using the external standard method with analytical solutions of known concentrations mixed with the internal standard. The results obtained by gas-chromatography analysis were compared with the results obtained by iodometric method (ethanol) and spectrophotometry (methanol), and the results were similar.

Integration of the peaks obtained by gaschromatography analysis of a sample of gastric content 


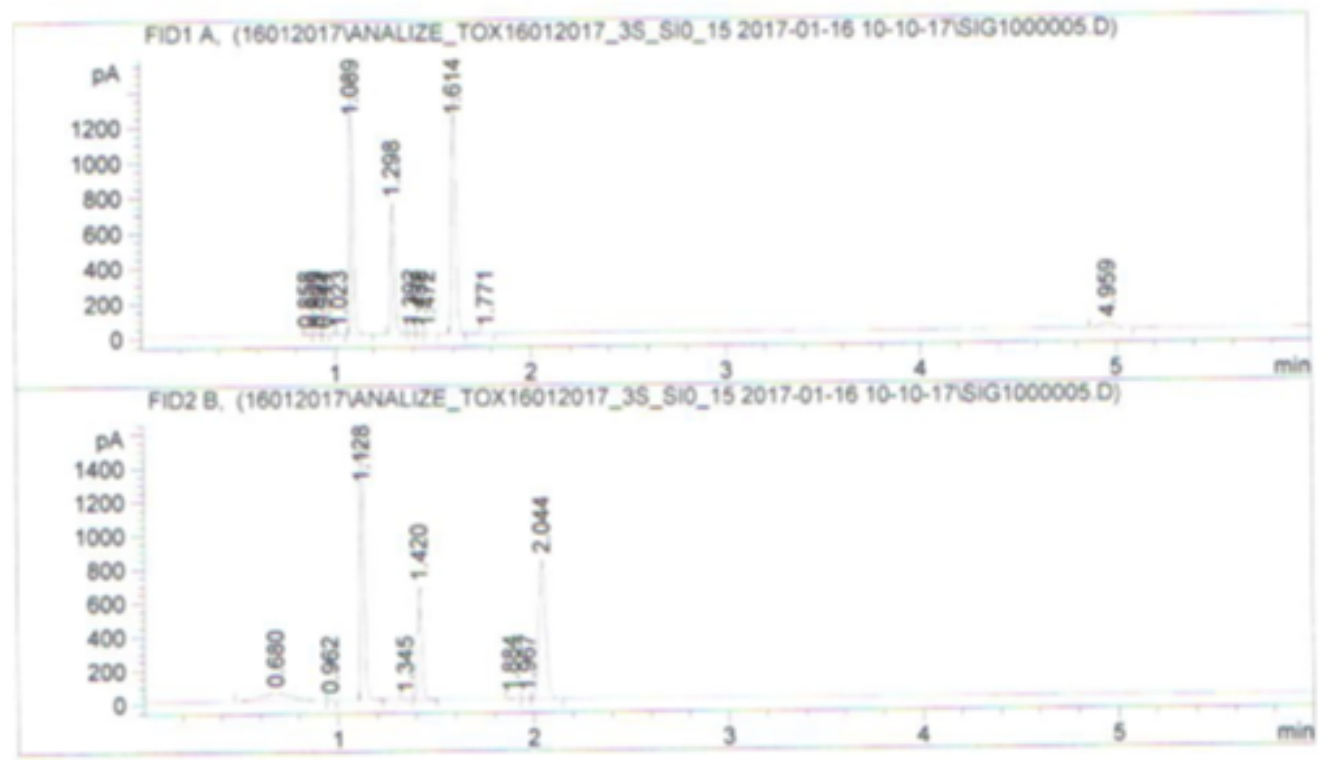

Fig. 1. The chromatogram obtained by analyzing one biologic sample (gastric content) with high methanol concentration (fig. 1) indicates the presence of methanol in that specific sample, in higher concentration comparative to ethanol.

The values obtained for retention time specific for each alcohol depend on the column characteristics. It is noted in the first pick-up box corresponding to FIDIA detector, the retention time (RT) for methanol was $1.089 \mathrm{~min}$, for ethanol 1.298 and for the internal standard 1.614.

In the second box (corresponding to FID2B detector) we can see the methanol at RT $1.128 \mathrm{~min}$, the ethanol at RT 1.420 and the internal standard at RT 2.044

FID1A detector corresponds to column DB-ALC1 and FID2B to column DB-ALC2.

Socio-demographic and medical data, together with the results of the toxicological analysis for some of the cases with methanol intoxication which resulted in the death of the patients are presented in table 1.

According to the literature data, the toxic level of blood methanol concentration is $0.20 \mathrm{~g} \%$, and concentrations of methanol in blood higher than $0.90 \%$ are considered lethal [21].

In our cases the blood levels were between $0.10 \mathrm{~g} \%$ and $2.95 \mathrm{~g} \%$ and in the gastric content between $0.15 \mathrm{~g} \%$ and $2.70 \mathrm{~g} \%$.

In one case was also performed the toxicological analysis on the product (liquid) consumed by one of the victims which showed that it is an aqueous solution which contains $4.7 \%(\mathrm{~m} / \mathrm{v})$ ethyl alcohol, $14.3 \%(\mathrm{~m} / \mathrm{v})$ methyl alcohol, ethyl salicylate, methyl salicylate, methylene blue and traces of salicylic acid.

The concentration of ethanol in the analyzed biological samples (blood, urine, gastric content), collected during the autopsy, was $0 \mathrm{~g} \%$ in all cases. The faster metabolism rate of ethanol as compared to methanol, the presence in higher concentrations of methanol in the product considered to be involved in the intoxications, explains the negative results regarding ethanol.

The investigation conducted in this case started from the suspicion that the victims had consumed sanitary alcohol, a product which they regularly drank and the results of the investigation supported this hypothesis. A number of companies which manufacture sanitary alcohol were suspected of tampering with the content. Samples were taken for toxicological examination from 5 manufacturers of sanitary alcohol, out of the ones which came under suspicion. The tests performed showed that bottles contained only ethanol. Methanol was not identified in any of the samples taken.

The prosecutors were already on alert. It looked like the identification of the methanol source which caused already many deaths was not going to be discovered.

After more than 20 deaths were registered, a plastic bottle with the label indicating the name of the product was found in one of the victims' house. That product was placed on the market shortly before the occurrence of the methanol intoxication cases reported in the present paper. The appearances of the recipients containing sanitary alcohol and the investigated liquid were almost the same, as well as their weight. Their color is bluish and they have an identical smell. However, the price of the latter is much lower than the price of the sanitary alcohol. The composition and toxicity of the two products is also very different. Toxicological analysis of the suspect product found that it contained $60 \%$ methanol, although on the product's label it was written to contain only ethanol. The investigations conducted by the Police, later determined thatall the victims had consumed that product. The product was immediately withdrawn from the market.

Sanitary alcohol, commonly called rubbing alcohol, is obtained from refined ethanol ( $70 \%$ volume), softened water, and disinfectants (methylene blue and ethyl salicylate in amounts established by the Romanian Ministry of Health) [2]. The effects and the toxicity of sanitary alcohol consumption on the body are similar to the ones of the ethanol $[10,22]$. The difference between sanitary alcohol and hard spirits which contain ethanol is that the sanitary alcohol has a higher concentration of ethanol, which means that when drinking a much smaller amount, of about $1 / 2$ compared to "moonshine" or other alcoholic beverage, it will lead to the onset of acute alcohol intoxication symptoms, respectively coma and death [3, 23]. Another difference from the other spirits is the lower cost and the easy accessibility to purchase it. For these reasons, in many areas of the country (including the county in which the cases presented in this paper occurred), it is preferred by the chronic ethanol consumers, thus replacing the consumption of spirits [ 7,24$]$.

The product which was at the origin of the collective intoxication presented in this paper is a counterfeit rubbing alcohol, produced by a manufacture in the county where 
Table 1

CASES IN WHICH THE PATIENTS DIED - SOCIO-DEMOGRAPHIC AND MEDICAL DATA AND THE RESULTS OF THE TOXICOLOGICAL ANALYSIS

\begin{tabular}{|c|c|c|c|c|c|c|c|c|c|}
\hline \multirow[t]{2}{*}{ Case } & \multirow[t]{2}{*}{ Sex } & \multirow{2}{*}{$\begin{array}{c}\text { Age } \\
\text { (years) }\end{array}$} & \multirow[t]{2}{*}{ Death diagnosis } & \multirow[t]{2}{*}{ Associated diseases } & \multirow{2}{*}{$\begin{array}{c}\text { Provenience } \\
\text { area }\end{array}$} & \multirow{2}{*}{$\begin{array}{c}\text { Death } \\
\text { circumstance }\end{array}$} & \multicolumn{3}{|c|}{ Methanol conc. (g\%o) } \\
\hline & & & & & & & Blood & $\begin{array}{l}\text { Gastric } \\
\text { content }\end{array}$ & Urine \\
\hline 1. & $\mathrm{M}$ & 32 & $\begin{array}{l}\text { Acute methanol } \\
\text { intoxication }\end{array}$ & $\begin{array}{l}\text { Scarred myocardial } \\
\text { infarction } \\
\text { Myocardial sclerosis } \\
\text { Atheromatosis } \\
\text { Fatty liver dystrophy }\end{array}$ & Rural & Death at home & 2.95 & 2.70 & - \\
\hline 2. & $\mathrm{M}$ & 53 & $\begin{array}{l}\text { Acute methanol } \\
\text { intoxication }\end{array}$ & $\begin{array}{l}\text { Myocardial sclerosis } \\
\text { Atheromatosis } \\
\text { Liver steatosis }\end{array}$ & Rural & Death at home & 2.50 & 2.25 & - \\
\hline 3. & $\mathrm{M}$ & 56 & $\begin{array}{l}\text { Acute methanol } \\
\text { intoxication }\end{array}$ & $\begin{array}{l}\text { Myocardial sclerosis } \\
\text { Atheromatosis } \\
\text { Liver steatosis }\end{array}$ & Rural & Death at home & 1.90 & 1.70 & - \\
\hline 4 & $\mathrm{M}$ & 45 & $\begin{array}{l}\text { Acute methanol } \\
\text { intoxication }\end{array}$ & $\begin{array}{l}\text { Fatty liver dystrophy } \\
\text { Chronic pancreatitis } \\
\text { Chronic alcoholism }\end{array}$ & Rural & $\begin{array}{l}\text { Death at home, } \\
\text { known as } \\
\text { chronic sanitary } \\
\text { alcohol } \\
\text { consumer }\end{array}$ & 1.71 & - & 2.01 \\
\hline 5. & $\mathrm{M}$ & 56 & $\begin{array}{l}\text { Acute methanol } \\
\text { intoxication }\end{array}$ & $\begin{array}{l}\text { Myocardial sclerosis } \\
\text { Systemic } \\
\text { atheromatosis } \\
\text { Liver steatosis }\end{array}$ & Rural & Death at home & 1.57 & 1.21 & \\
\hline 6. & $\mathrm{M}$ & 60 & $\begin{array}{l}\text { Acute methanol } \\
\text { intoxication }\end{array}$ & $\begin{array}{l}\text { Myocardial sclerosis } \\
\text { Aortic atheromatosis } \\
\text { Liver steatosis }\end{array}$ & Rural & $\begin{array}{l}\text { Found } \\
\text { unconscious, } \\
\text { possible } \\
\text { ingestion of } \\
\text { sanitary alcohol }\end{array}$ & 1.13 & 1.23 & \\
\hline 7. & $\mathrm{M}$ & 43 & $\begin{array}{l}\text { Acute methanol } \\
\text { intoxication }\end{array}$ & $\begin{array}{l}\text { Myocardial sclerosis } \\
\text { Aortic atheromatosis } \\
\text { Liver steatosis }\end{array}$ & Rural & $\begin{array}{l}\text { Death in } \\
\text { hospital }\end{array}$ & 0.87 & 0.73 & \\
\hline 8. & $\mathrm{M}$ & 50 & $\begin{array}{l}\text { Acute methanol } \\
\text { intoxication }\end{array}$ & - & - & $\begin{array}{l}\text { Consumption of } \\
\text { sanitary alcohol } \\
\text { at home, } \\
\text { transported in } \\
\text { coma to the } \\
\text { hospital where } \\
\text { he died }\end{array}$ & 0.59 & & 0.37 \\
\hline 9. & $\mathrm{M}$ & 54 & $\begin{array}{l}\text { Acute methanol } \\
\text { intoxication }\end{array}$ & Ethylic myocarditis & - & $\begin{array}{l}\text { Consumption of } \\
\text { sanitary alcohol } \\
\text { at home, } \\
\text { transported in } \\
\text { coma to the } \\
\text { hospital where } \\
\text { he died }\end{array}$ & 0.33 & & 0.47 \\
\hline 10. & $\mathrm{M}$ & 63 & $\begin{array}{l}\text { Acute methanol } \\
\text { intoxication }\end{array}$ & $\begin{array}{l}\text { Myocardial dystrophy } \\
\text { Aortic and coronary } \\
\text { athteromatosis }\end{array}$ & Rural & $\begin{array}{l}\text { Death in } \\
\text { hospital }\end{array}$ & 0.17 & & \\
\hline 11. & $F$ & 54 & $\begin{array}{l}\text { Acute methanol } \\
\text { intoxication }\end{array}$ & $\begin{array}{l}\text { Myocardial sclerosis } \\
\text { Liver cirrhosis with } \\
\text { ascites }\end{array}$ & Urban & $\begin{array}{l}\text { Death in } \\
\text { hospital }\end{array}$ & 0.13 & 0.15 & \\
\hline 12. & $F$ & 57 & $\begin{array}{l}\text { Acute methanol } \\
\text { intoxication }\end{array}$ & - & Urban & $\begin{array}{l}\text { Death in } \\
\text { hospital }\end{array}$ & 0.10 & & 0.06 \\
\hline
\end{tabular}

the intoxications occured. It is a skin care product with antiseptic effect, as fine printed on the label, containing, according to the same label, a $37 \%$ ethanol [4]. In fact, as showed by the results of the toxicological analysis of the content of the bottle and by the toxicological examinations performed on the organ samples collected during the autopsy from the dead victims, this product had a $60 \%$ concentration of methanol.

There were also very few cases of acute methanol poisoning where people actually survived (5 cases out of 40), but unfortunately they were left with sequelae blindness. For these cases, the methanol concentration in the blood was not determined because the patients were admitted to the hospital, and at the moment of their admission no toxicological analysis was indicated. The methanol intoxication diagnosis in the clinics where these patients were hospitalized and treated was based on the symptoms presented during hospitalization and survey data (all victims consumed the same product). Forensic expertise in the surviving victims was required after a long time since their admission in the hospital, at which time detection of methanol was negative due to its metabolism in the body and its elimination through the expired air and urine.

Methanol, also called carbinol, is a toxic product for the human body, which in small amounts damages the optic nerve and causes blindness and in large amounts causes death due to its liver and kidney toxicity $[9,25]$. The lethal dose is $0.15 \mathrm{~g} / \mathrm{kg}$ body weight, which for a person of $60 \mathrm{~kg}$ is about $9 \mathrm{~g}$.

The toxicity of methanol is the result of its metabolism in the liver and kidney in formic aldehyde and formic acid, metabolites responsible for the morphopathological changes which occur in acute intoxication $[2,17]$. 


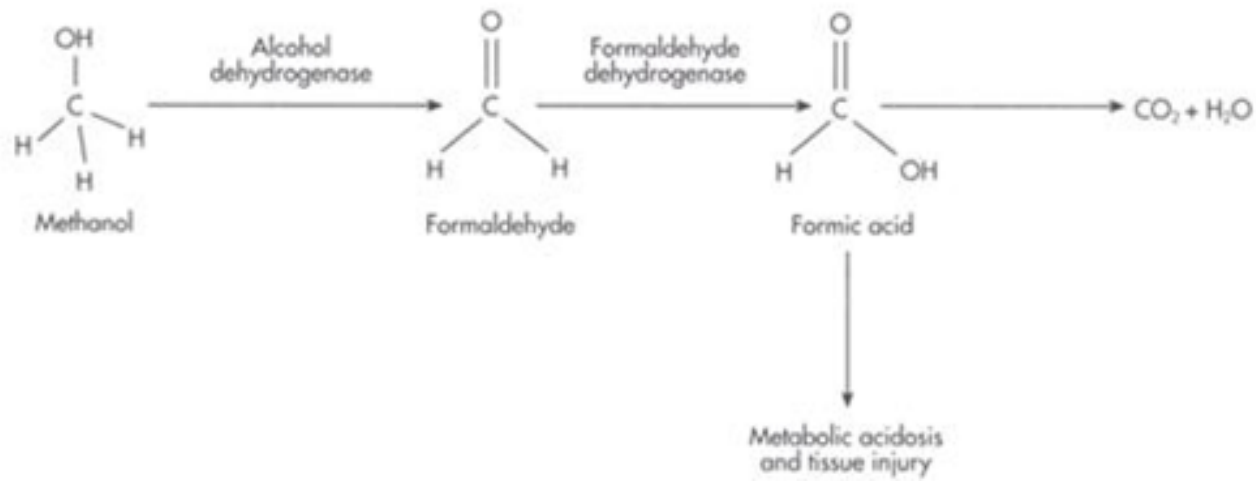

Fig. 2. Metabolism chain of methanol

Metabolism of methanol is carried out in several stages under the action of certain enzymes for each step: the first step is carried out under the action of the hepatic alcohol dehydrogenase to form formaldehyde, the second stage is carried out under the action of aldehyde dehydrogenase to form formic acid and in the third step the formic acid is oxidized under the influence of folic acid to obtain water and carbon dioxide (fig. 2) [26].

The metabolization rate of methanol is one-tenth of that of ethanol, stages 1 and 3 being limited in speed. As a result, formic acid accumulates in tissues, causing metabolic acidosis, responsible for clinical manifestations and death [2]. In severe intoxications lactic acid accumulates due to the inhibition of mitochondrial respiration and hypoxia produced by molds. Methanol also lowers the $\mathrm{NAD}^{+} / \mathrm{NADH}$ ratio with the predominance of anaerobic glycolysis and the consequent increase in lactate production. All these changes contribute to anionic hiatus in metabolic acidosis.

Cellular anoxia and metabolic acidosis determine pulmonary, renal, retinal, bulbar and central nucleus hemorrhages, and gross degeneration of the liver $[27,28]$. The formic acid methyl ester (methyl formate), another metabolite of methanol, is the one that, due to its liposolubility, acts adversely on the optic nerve, causing degenerative lesions, including retinal lymph nodes [2].

From the clinical point of view methanol poisoning is characterized by severe clinical phenomena which may be rapidly fatal [24]. The intoxication occurs after a latent period of 1 to 36 hours [29]. The state of insobriety appears, together with other symptoms like: dizziness, weakness, strong headaches, drowsiness, vomiting, diarrhea, abdominal pain, cyanosis of the face, profuse sweating, tachycardia, dyspnea, and arterial hypotension $[2,29]$. The state of coma is being installed, accompanied by agitation, tetanic contractions, sometimes seizures, hypothermia and acute pulmonary edema [2]. Visual impairment appears precociously (blurred vision, altered color perception) [4, 30]. Metabolic acidosis which also occurs is an important negative prognosis factor $[4,29,31]$. The patients intoxicated with methanol should be clinically monitored for a minimum of 5 days (time required to metabolize and eliminate the methanol from the body) [4, 32].

A particular feature of this unfortunate casualty was the fact that for the first time in Romania, the kidneys and liver of the patients in cerebral death were removed for transplant after receiving the permission from the family and the preparation of other legal procedures $[33,34]$. The organs harvested for transplantation were initially detoxified by hemodialysis immediately after the patient's hospitalization and later the transplants were performed.

\section{Conclusions}

Methanol intoxication in the studied geographical area is rare, amounting to 1 to 2 reported cases per year. For the first time in the history of the county there was a mass methanol intoxication with a large number of deaths due to improper consumption of an alcoholic parapharmaceutical product, which was meant only for external use, and could be purchased at a low price in the grocery stores. That para-pharmaceutical product contained $60 \%$ methanol, without this fact being mentioned on the label. The severity of the methanol intoxication following the consumption of that product was very high, as patients were hospitalized in coma, followed by their death within the next 3 to 4 days; only 5 out of the 40 victims have survived.

This case showed the importance of the proper labbeling of the para-pharmaceutical products and also their proper use, emphasizing on one hand the responsibility of the manufacturers and on the other hand the importance of the sanitary education of population.

\section{References}

1***https://ww w.who.int/substance_abuse/publications/ global_alcohol_report/profiles/rou.pdf?ua $=\overline{1}$

2.BELIS, V.. Tratat de Medicina Legala. Ed. Medicala, Bucharest, 1995, p. 234-245.

3.BELIS, V, Toxicological, clinical and forensic aspects in alcoholism. Ed. Medicala, Bucharest, 1988.

4.MOGOS, G., SITCAI N., Clinical toxicology. Ed. Medicala, Bucharest, 1988.

5.LIU, J.J ., DAYA, M.R., CARRASQUILLO, O., KALES, S.N.J.Toxicol. Clin. Toxicol., 36,no. 3, 1998, p. 175.

6.POPA, M.G., NEGURESCU, N., PANA, C., Rev. Chim (Bucharest), 56, no. 5,2005, p. 552.

7.JUDEA-PUSTA, C., RUSU, A., CAMARASAN, A., Aggress. Violent Behav., 47, 2019, p.68. https://doi.org/10.1016/j.avb.2019.03.006

8.MIHALACHE, G., BUHAS, C., RAHOTA, D., Rom. J. Leg. Med., 19, nr. 1, 2011, p. 69

9.DRESSLER, M.L., et al. The Death generating syndrome in acute alcoholic intoxication of the suckings. The $X \mathrm{XI}^{\text {th }}$ International Congress of the European Association of Poison Centres and Clinical Toxicologists, Vienna, April 12-15, 1994.

10.ALLALI-HASSANI, A., MARTINEZ, S.E., PERALBA, J.M., VAGLENOVA, J., VIDAL, F., RICHART,C., FARRES, J., PARES, X.FEBS Lett., 405, no. 1,1997, p. 26.

11.IOAN, B.G., ALEXA, T., ALEXA, I. Rom. J. Leg. Med., 22, no. 2, 2014, p. 127

12.IOAN, B., ALEXA, T., ALEXA, I. Rom. J. Leg. Med., 20, no. 4, 2012, p. 307

13.BUHAS, C. Aggress. Violent Behav., 18, no. 4, 2013 p. 434.

14.BUHAS, C.L., MIHALACHE, G., JUDEA-PUSTA, C.T., BUHAS, B., JURCA, M.C., IOVAN, C. Rom. J. Leg. Med., 26, no. 3, 2018, p. 249.

15.JUDEA-PUSTA, C.T., MUTIU, G., PASCALAU, A.V., BUHAS, C.L., CIURSAS, A.N., NISTOR-CSEPPENTO, C.D., BODEA, A., JUDEA, A.S., VICAS, R.M., DOBJ ANSCHI, L., POP, O.L. Rom. J. Morphol. Embryol., 59, no. 3, 2018, p. 965.

16.BUHAS, C., MIHALACHE, G., BUHAS, B., BUNGAU, S. Rom. J. Leg. Med., 24, no. 4, 2016, p. 300. 
17. BRUJA, N., IONECU-VISAN, I. Laboratory Diagnosis in Acute Poisoning. Ed. Militara, Bucharest, 1987.

18. COTRAU, M., PROCA, M. Toxicologie Analiticã. Ed. Militara, Bucharest, 1988.

19. IOAN, B.G., JITARU, V., DAMIAN, R., DAMIAN, S.I. Rom. J. Leg. Med., 23, no. 3, 2015, p. 211

20. HANGANU, B., VELNIC, A.A., MANOILESCU, I.S., IOAN, B.G. Postmodern Openings, 8, no. 3, 2017, p. 12

21. SCHULZ, M., SCHMOLDT, A. Pharmazie, 58, 2003, p. 447.

22.LIEBER, C.S. N. Engl. J. Med.,319, 1998, p. 1639.

23.CROW, K.E., BATT, R.D.Human Metabolism of Alcohol. Vol I., Pharmacokinetics, Medicolegal Aspects ad General Interest, CRC Press, Inc. Boca Raton, Florida, 1989.

24.FISHER, J.C., MASON, R.L., FISHER, J.V.J. Stud. Alcohol., 37, no. 9, 1976, p. 1247.

25. NARAYAN REDDY, K.S. The Essentials of Forensic Medicine and Toxicology.Nineteenth Edition, Published by K Suguna Devi, Malakpet, Hyderabad, 2000, p. 322.
26. BUHAS, C., MIHALACHE G. Interdisciplinary connections between legal medicine and emergency medicine. Ed. Univ. Oradea, 2006.

27. DIACONU, C., BALACEANU, A., COSTACHE, C. Journal of Hepatology, 60, Supplement 1, 2014, p. S515-S515.

28. PARASCHIV, B., TOMA, C.L., DIACONU, C. Archivos de Bronconeumología, 49, no. 7, 2013, p. 315-316.

29. BELIS, V. Guidebook of medical and forensic emergency. Ed. Medicala, Bucharest, 1995, p. 188.

30. ZAKHAROV, S., NAVRATIL, T., PELCLOVA, D. Monatshefte fur Chemie,146, no. 5, 2015, p.787.

31. HASSANIAN-MOGHADDAM, H., PAJOUMAND, A., DADGAR, S.M., SHADNIA, SH. Hum. Exp. Toxicol., 26, no. 7, 2007, p. 583.

32. ZAKHAROV, S., PELCLOVA, D., NAVRATIL, T., BELACEK, J., KURCOVA, I., KOMZAK, O., SALEK, T., LATTA, J., TUREK, R., BOCEK, R., KUCERA, C., HUBACEK, J .A., FENCLOVA, Z., PETRIK, V., CERMAK, M., HOVDA, K.E. Kidney Int., 86, no. 1, 2014, p. 199.

33.IOAN, B.G., ASTARASTOAE, V. Rev. Rom. Bioet., 5, no.1,2007, p. 81 34. IORGA, M., DONDAS, C., IOAN, B.G., TOADER, E. Rev. Cercet. Interv. Soc., 56, 2017, p. 5

Manuscript received:17.11.2018 